GSA Data Repository 2010

Table DR1

.




.

MIDDLE CAMBRIAN Cambrian Series 3

\section{Table DR2}

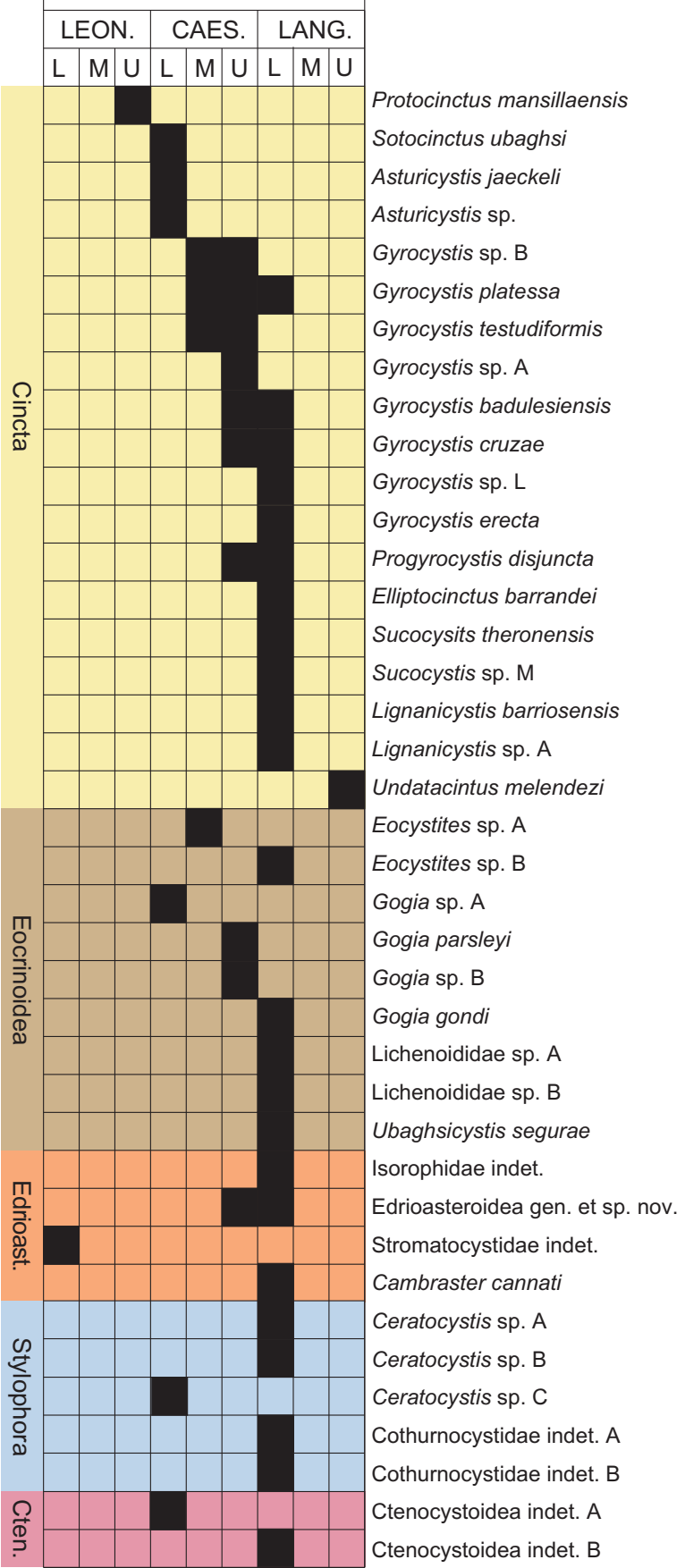

